\title{
Assessment of Groundwater Quality in the Dogger Aquifer of Poitiers, Poitou-Charentes Region, France
}

\author{
Amani Shorieh, Gilles Porel, Moumtaz Razack* \\ Department of Hydrogeology, University of Poitiers, Poitiers, France \\ Email: ${ }^{\text {moumtaz.razack@univ-poitiers.fr }}$
}

Received 25 January 2015; accepted 9 February 2015; published 12 February 2015

Copyright (C) 2015 by authors and Scientific Research Publishing Inc.

This work is licensed under the Creative Commons Attribution International License (CC BY). http://creativecommons.org/licenses/by/4.0/

\section{(c) (7) Open Access}

\section{Abstract}

The Poitou-Charentes, located in the Center-West of France, is a region where economy is based mainly on agriculture. This region, made up of 4 Departments (Vienne, Charente, Charente Maritime, Deux-Sèvres), is supplied largely by groundwater exploitation, both for consumption and for irrigation. This resource is thus vital to the region and its preservation is a major issue. The objective of this study is the determination of the groundwater quality in the Dogger aquifer of Poitiers (Vienne Department), which is the main water resource for this area and to achieve a better understanding of the factors influencing groundwater mineralization. Sixty-six wells, distributed over the study area, were sampled and analyzed for major ions $\left(\mathrm{Ca}^{2+}, \mathrm{Mg}^{2+}, \mathrm{Na}^{+}, \mathrm{K}^{+}, \mathrm{HCO}_{3}^{-}, \mathrm{Cl}^{-}\right.$, $\mathrm{SO}_{4}^{2-}, \mathrm{NO}_{3}^{-}$). Data were interpreted using graphical (Piper diagram, binary diagrams) and statistical methods (correlation matrix, principal components analysis). Saturation and chloro-alkaline indices were also computed. It is shown that the groundwater mineralization is mainly associated with $\mathrm{Ca}^{2+}, \mathrm{K}^{+}, \mathrm{HCO}_{3}^{-}, \mathrm{Cl}^{-}, \mathrm{SO}_{4}^{2-}$, and $\mathrm{NO}_{3}^{-}$. Hydrochemistry of groundwater is determined by both natural processes, and anthropogenic factors. Natural factors are dissolution of carbonate and dolomitic minerals, and cation exchanges with clays, while anthropogenic factors are contaminant infiltration with waste waters and agricultural fertilizers. Nitrate is the main contaminant found in the groundwater and makes this resource unsuitable for consumption at some places.

\section{Keywords}

Groundwater, Hydrochemistry, Principal Component Analysis, Pollution, Dogger Aquifer, Poitiers

\footnotetext{
"Corresponding author.
}

How to cite this paper: Shorieh, A., Porel, G. and Razack, M. (2015) Assessment of Groundwater Quality in the Dogger Aquifer of Poitiers, Poitou-Charentes Region, France. Journal of Water Resource and Protection, 7, 171-182. 


\section{Introduction}

Groundwater is an essential source of water supply in many parts in the world due to its large volumes and its low vulnerability to pollution when compared to surface waters [1]. Nowadays, groundwater resources play an important role in meeting demands on water supply because of scanty surface-water sources or their unsuitability. Due to population growth and increase of economic activities (industries, agriculture), groundwater resources are more and more under stresses. They are over-exploited leading to critical levels. Pollution of groundwater is also a major issue because these resources are inherently susceptible to contamination from land use and anthropogenic and other activities impacts. In agricultural areas, the use of fertilizers is a main source of groundwater pollution. Once pollution enters the subsurface environment, it may remain concealed for many years and render groundwater supplies unsuitable for consumption and other uses. Preventing groundwater pollution is necessary for effective groundwater resource management. An initial step toward sustainable groundwater resource management involves understanding groundwater quality and processes of mineralization.

This paper is focused on the Dogger aquifer of Poitiers, in the Poitou-Charentes Region, Center West of France (Figure 1). The Region is made up of 4 Departments (Vienne, Charente, Charente Maritime, DeuxSèvres). The Dogger aquifer is of vital importance for the socio-economic development of this region, specifically for the Vienne Department, supplying the needs of almost the entire domestic and irrigation demands. Total water volumes collected in 2010 amounted to 81 million $\mathrm{m}^{3}$, and are mainly used for drinking water and agriculture (Table 1). 66 million $\mathrm{m}^{3}$ are taken from groundwater, which is more than $80 \%$ of the total volume. Agriculture is the dominant economic activity in the region and uses 48 million $\mathrm{m}^{3}$, which represents $60 \%$ of the total volume. Groundwater accounts for $81 \%$ of this volume. These statistics place great emphasis on the vital importance of groundwater for this region. This study attempts to evaluate the hydrogeochemical processes controlling the groundwater composition in this unconfined aquifer.

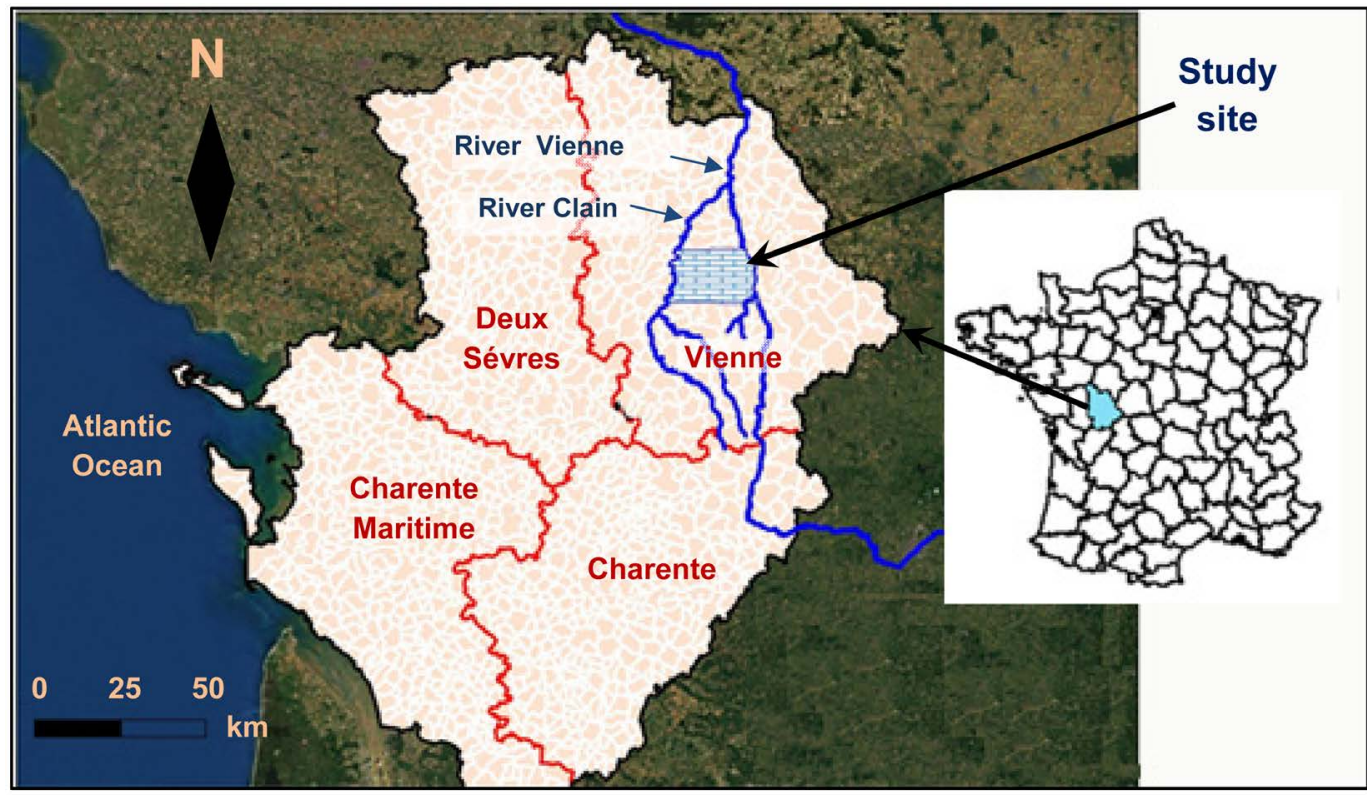

Figure 1. Location of the study area in the Vienne department, Poitou-Charentes region, center west France.

Table 1. Volumes of water (Mm³/year) used in the department of Vienne in 2010/11. Source: http://sigespoc.brgm.fr/

\begin{tabular}{cccc}
\hline & Groundwater & Rivers & Total \\
\hline Drinking water & $27(82 \%)$ & $6(18 \%)$ & $33(100 \%)$ \\
Agriculture & $39(81 \%)$ & $9(19 \%)$ & $48(100 \%)$ \\
& $66(81 \%)$ & $15(19 \%)$ & $81(100 \%)$ \\
\hline
\end{tabular}




\section{Study Site: Geology and Hydrogeology}

The study area is located between two main rivers, Clain and Vienne, and receives an average annual rainfall of $750 \mathrm{~mm}$. The surface of the study area is about $500 \mathrm{~km}^{2}$. The study area is at the crossroads of four major geological units: the sedimentary formations of the Paris Basin in the north-east and the Aquitaine Basin in the south-west and the schist and granite massifs of the Armorican Massif to the north-west, and the Central Massif in the south east. The threshold of Poitou is at the interface of these units (Figure 2). From a geological point of view, in the study area, the Mesozoic series covers the granite basement previously subjected to severe erosion. Above this basement, which outcrops locally in the valleys (Ligugé Champagné St Hilaire...), lies the Lias series which consist of various facies (clay, sand, limestone and dolomites). The Infra-Toarcian contains a confined aquifer with a relatively thin (tens of meters) but karstic and fractured reservoir. It is confined under marly formations (Figure 2).

Above the Lias, lies the Dogger limestones in which karst is well developed. This karst massif is in the form of plateaus. The limestones are overlain by sandy clay soil, alteration products combined with fluvial and aeolian deposits. These formations, which coverall most all the Dogger, store rain water but generally have poor permeability. They slowly supply with water the underlying karst aquifers evidenced by the many karstic features (sinkholes, closed depressions...) that can be observed. To the north, more recent formations outcrop: the Upper Jurassic limestones (Malm), and Cretaceous clays and limestones.

The confined Lias aquifer is unaffected by surface pollution. However, it has undesirable natural elements (fluorine, arsenic) which often exceed the standards for drinking water concentration. The limestone aquifer of the Middle Jurassic (Dogger) is the main water resource whether for irrigation or drinking water. This particularly vulnerable karstic and unconfined aquifer of ten has a poor quality (contamination by nitrates and pesticides from agriculture). The thickness of this aquifer is important to the north and south of the basin, but is strongly reduced in the central part (bulging of Poitou threshold) and even disappears completely at the Champagné Saint Hilaire and Ligugehorsts (Figure 2). Alluvial aquifers and that of the Cretaceous (Cenomanian), downstream of Poitiers, are unproductive.

A piezometric campaign of the Dogger aquifer has been conducted in November 2012. Around one hundred wells and boreholes have been inventoried and helped establish the piezometric map of the groundwater (Figure 3). The piezometric map shows that the groundwater is drained by the Clainriverto the West and the Vienne river to the East. A groundwater dividing line separates the basins of Clain and Vienne. However underground basins do not generally correspond to surface topographic watersheds. Groundwater depth is close to the soil surface in the valleys and ranges between $20 \mathrm{~m}$ to $40 \mathrm{~m}$ on the plateau between the rivers Clain and Vienne. Groundwater level fluctuates by a few meters on the plateau between low water period (August-September) and high water period (March-April).

\section{Methodology}

During the campaign of November 2012, 66 wells were sampled and analyzed to understand the chemical variations of groundwater (Figure 4). Samples collected were filtered using $0.45 \mathrm{~lm}$ pore size membrane and stored in polyethylene bottles which are initially washed with $10 \%$ of $\mathrm{HNO}_{3}$ and rinsed thoroughly with distilled water.

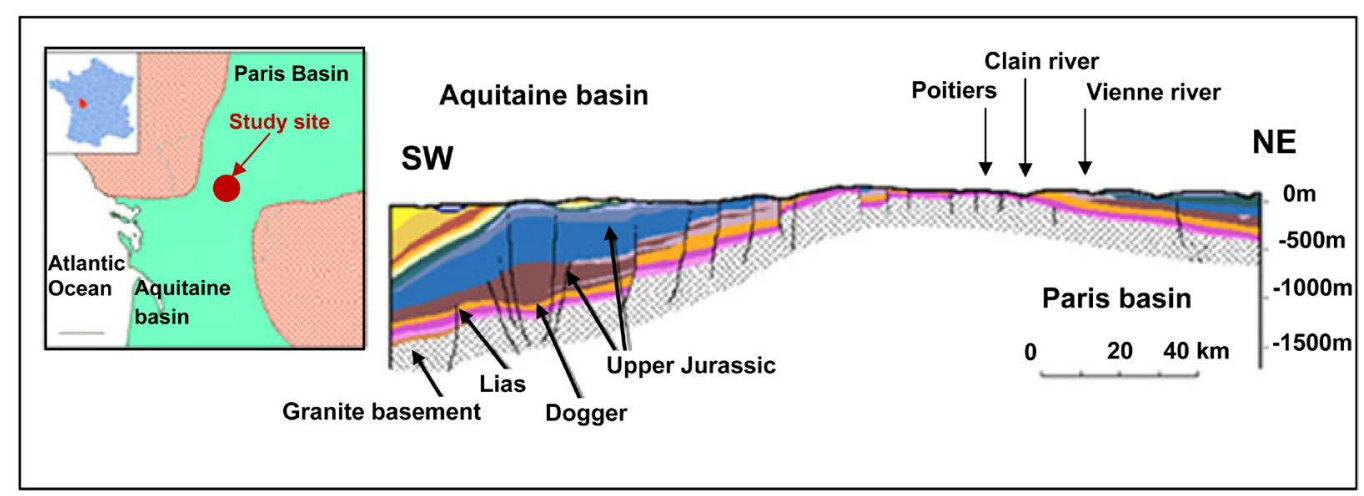

Figure 2. Geological SW-NE cross-section. Source BRGM, modified. 


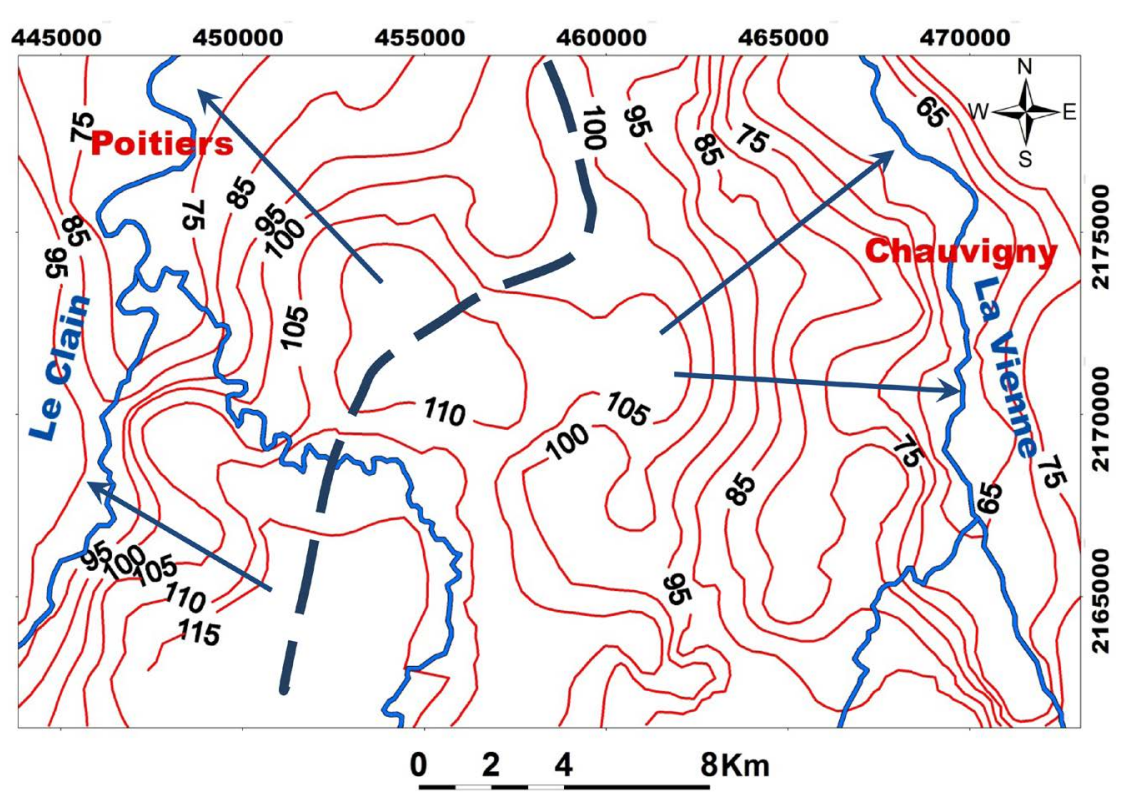

Figure 3. Piezometric map of the Dogger groundwater (November 2012).

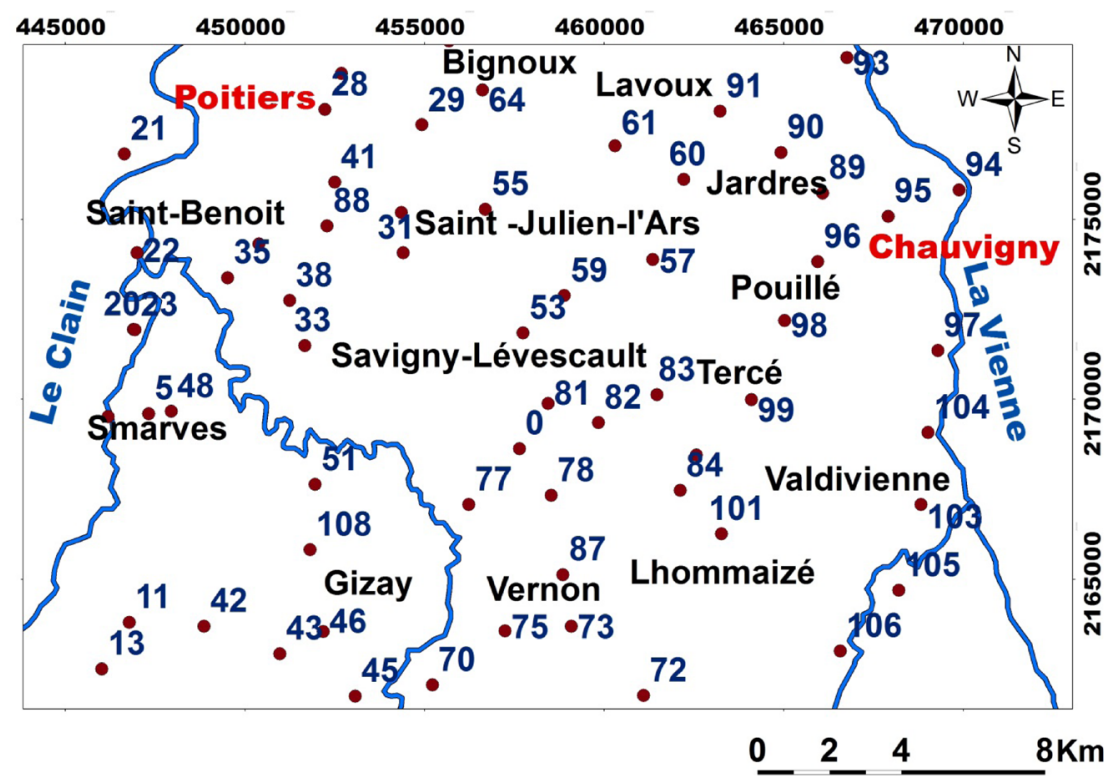

Figure 4. Location of the wells sampled for physico-chemical analyses.

Physical parameters like $\mathrm{pH}$, and electrical conductivity, were measured in the field with a multi-parameter set of WTW multi 350i brand. Major cations $\left(\mathrm{Na}^{+}, \mathrm{K}^{+}, \mathrm{Mg}^{2+}, \mathrm{Ca}^{2+}\right)$ were estimated by atomic absorption. $\mathrm{HCO}_{3}^{-}$was estimated by titrimetric method. $\mathrm{SO}_{4}^{2-}, \mathrm{Cl}^{-}$and $\mathrm{NO}_{3}^{-}$were estimated by chromatography. The analytical precision for the measurement was determined by calculating the ionic balance error, which is generally found to be within $\pm 5 \%$. Graphical methods (Piper diagram, binary diagrams) and statistical methods such as the correlation matrix and the principal components analysis were used to interpret the data.

\section{Results and Discussions}

\subsection{Descriptive Statistics}

Descriptive statistics (average, minimum, maximum, standard deviation) of all the analyzed parameters are 
reported in Table 2. The groundwater is moderately mineralized (average CE $=694 \mu \mathrm{S} / \mathrm{cm}$ ). The standard deviation for all variables is lower than the average value. This indicates that the chemical properties of the Dogger groundwater are not widely dispersed. The coefficient of variation of $\mathrm{Mg}^{2+}$ is the highest (CV =92.3\%), followed by $\mathrm{NO}_{3}^{-} \quad(\mathrm{CV}=83.3 \%)$. $\mathrm{Cl}^{-}, \mathrm{K}^{+}$and $\mathrm{Na}^{+}$have a $\mathrm{CV}>60 \%$. The dominant anion is bicarbonate. The order of importance of the anions is the following: $\mathrm{HCO}_{3}^{-}>\mathrm{NO}_{3}^{-}>\mathrm{Cl}^{-}>\mathrm{SO}_{4}^{2-}$. The average concentrations of $\mathrm{NO}_{3}^{-}$is $48 \mathrm{mg} / \mathrm{L}$, close to the standard value for drinking water which is $50 \mathrm{mg} / \mathrm{L}$. The dominant cation is calcium $\mathrm{Ca}^{2+}$ concentrations are greater than those of $\mathrm{Mg}^{2+}, \mathrm{Na}^{+}$and $\mathrm{K}^{+}$. The order of importance of the cations is $\mathrm{Ca}^{2+}>\mathrm{K}^{+}>\mathrm{Na}^{+}>\mathrm{Mg}^{2+}$. The average concentration of $\mathrm{Ca}^{2+}$ is $98 \mathrm{mg} / \mathrm{L}$, much higher than the average concentration of other cations $\left(\mathrm{Mg}^{2+}: 13 \mathrm{mg} / \mathrm{L} ; \mathrm{Na}^{+}: 19 \mathrm{mg} / \mathrm{L} ; \mathrm{K}^{+}: 30 \mathrm{mg} / \mathrm{L}\right)$.

\subsection{Diagram of Piper}

Results of the chemical analyses (major ions), plotted on the Piper diagram (Figure 5), clearly reveal a certain homogeneity of the Dogger groundwater hydrochemical composition. All samples display two major ions, bicarbonate and calcium. This shows that the calcium bicarbonate facies is the dominant one in this aquifer, except for two particular wells, 51 and 28. The concentrations of chemical elements in these two samples are abnormal. Well \#28 has a sodium bicarbonate facies. This well is located in Poitiers city, in Callovian limestones. The sodium concentration in this well is very high and equal to $134 \mathrm{mg} / \mathrm{L}$. Well \#51 has a chloride-sulfate and calciummagnesium facies. This well is located in a part of the aquifer covered by tertiary formations. The groundwater presents several elements in excess concentrations. The chloride content $(278 \mathrm{mg} / \mathrm{L})$ is much higher than the maximum value observed elsewhere $(77 \mathrm{mg} / \mathrm{L}$ ) on the remaining samples. Also the sulphate content reaches 55 $\mathrm{mg} / \mathrm{L}$, exceeding that of the other samples. Similarly, the potassium reaches $271.3 \mathrm{mg} / \mathrm{L}$. The presence of this facies can be linked to a very particular pollution from irrigation water.

It is assumed that chloride is not affected by chemical processes such as dissolution, precipitation, and especially hydro-morphic substitutions. So in a remote aquifer from marine influences, the origin of the chlorides can be mainly anthropogenic. Therefore these two wells were removed from the data for subsequent interpretation.

\subsection{Saturation Index}

The saturation index approach allows predicting the reactive mineralogy of the subsurface from groundwater data without collecting the samples of the solid phase and analyzing the mineralogy. The saturation index SI of a mineral is calculated based on the following equation [2]:

$$
\mathrm{SI}=\log \left(\frac{\mathrm{IAP}}{K_{\mathrm{s}}}\right)
$$

where IAP is the ion activity product and $K_{s}$ is the solubility product of the mineral.

Table 2. Descriptive statistics of the variables.

\begin{tabular}{|c|c|c|c|c|c|}
\hline Variable & Minimum & Maximum & Average & $\begin{array}{l}\text { Standard } \\
\text { deviation }\end{array}$ & $\begin{array}{l}\text { Coefficient of } \\
\text { variation (\%) }\end{array}$ \\
\hline Electrial conductivity ( $\mu \mathrm{s} / \mathrm{cm})$ & 241 & 1080 & 694 & 156 & 22.5 \\
\hline $\mathrm{HCO}_{3}^{-} \quad(\mathrm{mg} / \mathrm{L})$ & 204 & 580 & 354 & 78 & 22.0 \\
\hline $\mathrm{SO}_{4}^{2-} \quad(\mathrm{mg} / \mathrm{L})$ & 4 & 50 & 23 & 10 & 43.5 \\
\hline $\mathrm{NO}_{3}^{-} \quad(\mathrm{mg} / \mathrm{L})$ & 7 & 165 & 48 & 40 & 83.3 \\
\hline $\mathrm{Cl}^{-}(\mathrm{mg} / \mathrm{L})$ & 3 & 77 & 27 & 18 & 66.7 \\
\hline $\mathrm{Ca}^{2+}(\mathrm{mg} / \mathrm{L})$ & 51 & 159 & 98 & 26 & 26.5 \\
\hline $\mathrm{Mg}^{2+}(\mathrm{mg} / \mathrm{L})$ & 2 & 76 & 13 & 12 & 92.3 \\
\hline $\mathrm{Na}^{+}(\mathrm{mg} / \mathrm{L})$ & 1 & 54 & 19 & 13 & 68.4 \\
\hline $\mathrm{K}^{+}(\mathrm{mg} / \mathrm{L})$ & 2 & 100 & 30 & 24 & 80.0 \\
\hline
\end{tabular}




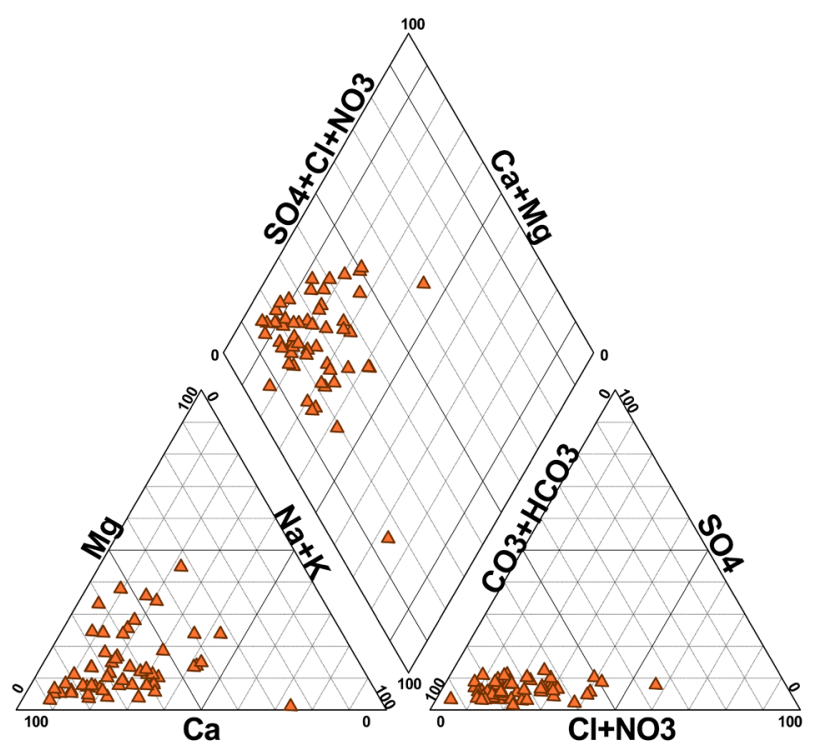

Figure 5. Piper diagram of the water samples taken in November 2012.

The PHREEQC package [3] was used to estimate the saturation index. SI indicates if a solution is in equilibrium, under-saturated or super-saturated with regard to a mineral. Equilibrium can be assumed for a range of -0.5 to 0.5 . If the SI value is below -0.5 , the solution is under-saturated with regard to the corresponding miner$\mathrm{al}$, if the SI exceeds +0.5 the water is super-saturated with respect to this mineral. Table 3 shows the statistics of the saturation indices for the minerals calcite, gypsum and halite in the collected water samples. Most of the samples were found in equilibrium or slightly saturated with calcite. The SI for calcite ranges between 0.01 to 1.2. The average SI for calcite is 0.72 . The SI for gypsum and halite ranges between -2.78 to -1.71 and -9.44 to -7.13 respectively. The average SI is -2.20 for gypsum and -9.44 for halite. This indicates that the groundwater is under-saturated with regards to these minerals. These findings explain why the major ions dissolve in the Dogger groundwater are $\mathrm{Ca}^{2+}$, and $\mathrm{HCO}_{3}^{-}$.

\subsection{Correlation Matrix}

A correlation matrix was computed considering all the physico-chemical variables (Table 4). This is in perspective to better appreciate associations among the various parameters. The critical value of the correlation coefficient, at $1 \%$ level of significance, was calculated using the following transform:

$$
R_{o b s} \rightarrow t=R_{o b s}(n-2)^{1 / 2} /\left(1-R_{o b s}^{2}\right)^{1 / 2}
$$

where $R_{o b s}$ is the observed correlation coefficient, $n$ is the sample size, $t$ is a statistics which follows a Student law with $n-2$ degrees of freedom. Details can be found in [4]. This yielded a critical correlation coefficient value $\left(R_{\text {critical }}\right)$ of 0.32 . Thus values of $R$ less than 0.32 are meaningless. Significant values of $R$ are highlighted in the correlation matrix (Table 4).

The correlation matrix shows that the electrical conductivity is correlated with bicarbonate $(R=0.67)$, sulphate $(R=0.46)$, nitrate $(R=0.48)$, chloride $(R=0.48)$, calcium $(R=0.50)$ and potassium $(R=0.61)$. The groundwater mineralization is mainly related to these elements. Bicarbonate is correlated with calcium $(R=$ $0.45)$, magnesium $(R=0.38)$ but also with potassium $(R=0.48)$. Sulphate displays significant correlations with chloride $(R=0.43)$ and sodium $(R=0.62)$. Chloride is well correlated with calcium $(R=0.50)$ and potassium $(R=0.42)$, and nitrate with chloride $(R=0.34)$ and calcium $(R=0.49)$. Some significant relations are related to the geological environment $\left(\mathrm{HCO}_{3}^{-}, \mathrm{Ca}^{2+}, \mathrm{Mg}^{2+}\right)$. Other relations exist between ions of same sign $\left(\mathrm{SO}_{4}^{2-}-\mathrm{Cl}^{-}\right)$ or ions of opposite sign $\left(\mathrm{SO}_{4}^{2-}-\mathrm{Na}^{+} ; \mathrm{NO}_{3}^{-}-\mathrm{Ca}^{2+} ; \mathrm{Cl}^{-}-\mathrm{Ca}^{2+} ; \mathrm{Cl}^{-}-\mathrm{K}^{+}\right.$). These relationships allow assuming a common origin for these elements from agricultural activities disturbing the natural hydrochemistry of the Dogger groundwater. 
Table 3. Descriptive statistics of the saturation indices.

\begin{tabular}{cccc}
\hline & Calcite & Gypsum & Halite \\
\hline Maximum & 1.2 & -1.71 & -7.13 \\
Minimum & 0.01 & -2.78 & -9.44 \\
Average & 0.72 & -2.20 & -8.09 \\
\hline
\end{tabular}

Table 4. Correlation matrix between variables.

\begin{tabular}{|c|c|c|c|c|c|c|c|c|c|}
\hline Variables & $\begin{array}{c}\text { EC } \\
\mu \mathrm{S} / \mathrm{cm}\end{array}$ & $\begin{array}{c}\mathrm{HCO}_{3}^{-} \\
(\mathrm{mg} / \mathrm{L})\end{array}$ & $\begin{array}{c}\mathrm{SO}_{4}^{2-} \\
(\mathrm{mg} / \mathrm{L})\end{array}$ & $\begin{array}{c}\mathrm{NO}_{3}^{-} \\
(\mathrm{mg} / \mathrm{L})\end{array}$ & $\begin{array}{c}\mathrm{Cl}^{-} \\
(\mathrm{mg} / \mathrm{L})\end{array}$ & $\begin{array}{c}\mathrm{Ca}^{2+} \\
(\mathrm{mg} / \mathrm{L})\end{array}$ & $\begin{array}{c}\mathrm{Mg}^{2+} \\
(\mathrm{mg} / \mathrm{L})\end{array}$ & $\begin{array}{c}\mathrm{Na}^{+} \\
(\mathrm{mg} / \mathrm{L})\end{array}$ & $\begin{array}{c}\mathrm{K}^{+} \\
(\mathrm{mg} / \mathrm{L})\end{array}$ \\
\hline $\mathrm{EC} \mu \mathrm{S} / \mathrm{cm}$ & 1 & & & & & & & & \\
\hline $\mathrm{HCO}_{3}^{-} \quad(\mathrm{mg} / \mathrm{L})$ & 0.671 & 1 & & & & & & & \\
\hline $\mathrm{SO}_{4}^{2-} \quad(\mathrm{mg} / \mathrm{L})$ & 0.463 & 0.252 & 1 & & & & & & \\
\hline $\mathrm{NO}_{3}^{-} \quad(\mathrm{mg} / \mathrm{L})$ & 0.486 & 0.041 & 0.206 & 1 & & & & & \\
\hline $\mathrm{Cl}^{-}(\mathrm{mg} / \mathrm{L})$ & 0.480 & 0.167 & 0.433 & 0.343 & 1 & & & & \\
\hline $\mathrm{Ca}^{2+}(\mathrm{mg} / \mathrm{L})$ & 0.507 & 0.452 & 0.103 & 0.490 & 0.506 & 1 & & & \\
\hline $\mathrm{Mg}^{2+}(\mathrm{mg} / \mathrm{L})$ & 0.300 & 0.384 & 0.172 & 0.116 & -0.004 & -0.250 & 1 & & \\
\hline $\mathrm{Na}^{+}(\mathrm{mg} / \mathrm{L})$ & 0.250 & 0.072 & 0.620 & 0.066 & 0.290 & -0.142 & 0.009 & 1 & \\
\hline $\mathrm{K}^{+}(\mathrm{mg} / \mathrm{L})$ & 0.610 & 0.482 & 0.279 & 0.191 & 0.419 & 0.332 & -0.025 & 0.066 & 1 \\
\hline
\end{tabular}

\subsection{Principal Component Analysis}

Principal Component Analysis (PCA) is a multivariate statistical method which has been successfully applied to study the hydrogeochemistry of aquifers [5]-[10]. The principle is to reduce the number of original variables by detecting the underlying relations. PCA explains a large amount of the variance of the analytical data by a small number of factors or principal components [6] [11]. The factor extraction is done using a minimum acceptable eigen value which should be greater than 1 [12] [13].

Table 5 shows the 5 first eigen values and the amount of total variance explained by each of them. The first three eigen values greater than one were kept for the analysis. Table 6 shows the factor loadings for each variable. Factor loading is the measure of the degree of relation between the variables and the factor.

Plots of the variables on the planes associated with factors 1-2 and factors 1-3 are shown on Figure 6. Factor 1 has high loadings for $\mathrm{EC}, \mathrm{HCO}_{3}^{-}, \mathrm{Ca}^{2+}, \mathrm{Cl}^{-}, \mathrm{Na}^{+}, \mathrm{SO}_{4}^{2-}, \mathrm{NO}_{3}^{-}$, and $\mathrm{K}^{+}$, except for $\mathrm{Mg}^{2+}$ and $\mathrm{Na}^{+}$. This factor is related mainly with the mineralization of the samples. The substantial contribution of nitrate in the study area results from the application of agricultural fertilizers in excess of the land capability conditions [14].

Factor 2 has high loadings for $\mathrm{SO}_{4}^{2-}, \mathrm{Ca}^{2+}$ and $\mathrm{Na}^{+}$and factor 3 for $\mathrm{Mg}^{2+}$ and $\mathrm{HCO}_{3}^{-}$. Factor 2 highlights some ions association that might be related to the use of fertilizers in the study area $\left(\mathrm{SO}_{4}^{2-}, \mathrm{Ca}^{2+}\right)$ or to base exchanges processes $\left(\mathrm{Na}^{+}\right)$. Factor 3 is related to $\mathrm{Mg}^{2+}$ and $\mathrm{HCO}_{3}^{-}$, which may result from the influx of these ions by dissolution from dolomitic rocks.

\subsection{Chloro-Alkaline Index}

The chloro-alkaline index (CAI) was used to define the ionic exchanges between water and the aquifer rocks [15]. The expression of the chloro-alkaline index (CAI) is as follows:

$$
\mathrm{CAI}=\mathrm{r} \frac{\mathrm{Cl}^{-}-\left(\mathrm{K}^{+}+\mathrm{Na}^{+}\right)}{\mathrm{Cl}^{-}}
$$

This ratio is positive when the sodium and potassium contents are low, i.e. when groundwater has been slightly in contact with minerals able to release these interchangeable cations easily. These exchanges of ions 
Table 5. Eigen values and explained variance.

\begin{tabular}{cccccc}
\hline & F1 & F2 & F3 & F4 & F5 \\
\hline Eigen value & 3.449 & 1.567 & 1.363 & 0.970 & 0.581 \\
Explained variance (\%) & 38.32 & 17.41 & 15.15 & 10.78 & 6.46 \\
Cumulated \% & 38.32 & 55.73 & 70.88 & 81.66 & 88.11 \\
\hline
\end{tabular}

Table 6. Factor loadings for the variables.

\begin{tabular}{cccc}
\hline & $\mathrm{F} 1$ & $\mathrm{~F} 2$ & $\mathrm{~F} 3$ \\
$\mathrm{EC} \mu \mathrm{S} / \mathrm{cm}$ & $\mathbf{0 . 9 0 5}$ & -0.013 & 0.203 \\
$\mathrm{HCO}_{3}^{-}(\mathrm{mg} / \mathrm{L})$ & $\mathbf{0 . 6 6 3}$ & -0.061 & $\mathbf{0 . 5 8 6}$ \\
$\mathrm{SO}_{4}^{2-}(\mathrm{mg} / \mathrm{L})$ & $\mathbf{0 . 6 1 5}$ & $\mathbf{0 . 6 0 3}$ & -0.217 \\
$\mathrm{NO}_{3}^{-}(\mathrm{mg} / \mathrm{L})$ & $\mathbf{0 . 5 4 0}$ & -0.244 & -0.215 \\
$\mathrm{Cl}^{-}(\mathrm{mg} / \mathrm{L})$ & $\mathbf{0 . 6 9 6}$ & -0.019 & -0.404 \\
$\mathrm{Ca}^{2+}(\mathrm{mg} / \mathrm{L})$ & $\mathbf{0 . 6 3 8}$ & $-\mathbf{0 . 6 3 2}$ & -0.191 \\
$\mathrm{Mg}^{2+}(\mathrm{mg} / \mathrm{L})$ & 0.212 & 0.382 & $\mathbf{0 . 7 3 6}$ \\
$\mathrm{Na}^{+}(\mathrm{mg} / \mathrm{L})$ & 0.347 & $\mathbf{0 . 7 5 3}$ & -0.371 \\
$\mathrm{~K}^{+}(\mathrm{mg} / \mathrm{L})$ & $\mathbf{0 . 6 8 1}$ & -0.165 & 0.079 \\
\hline
\end{tabular}
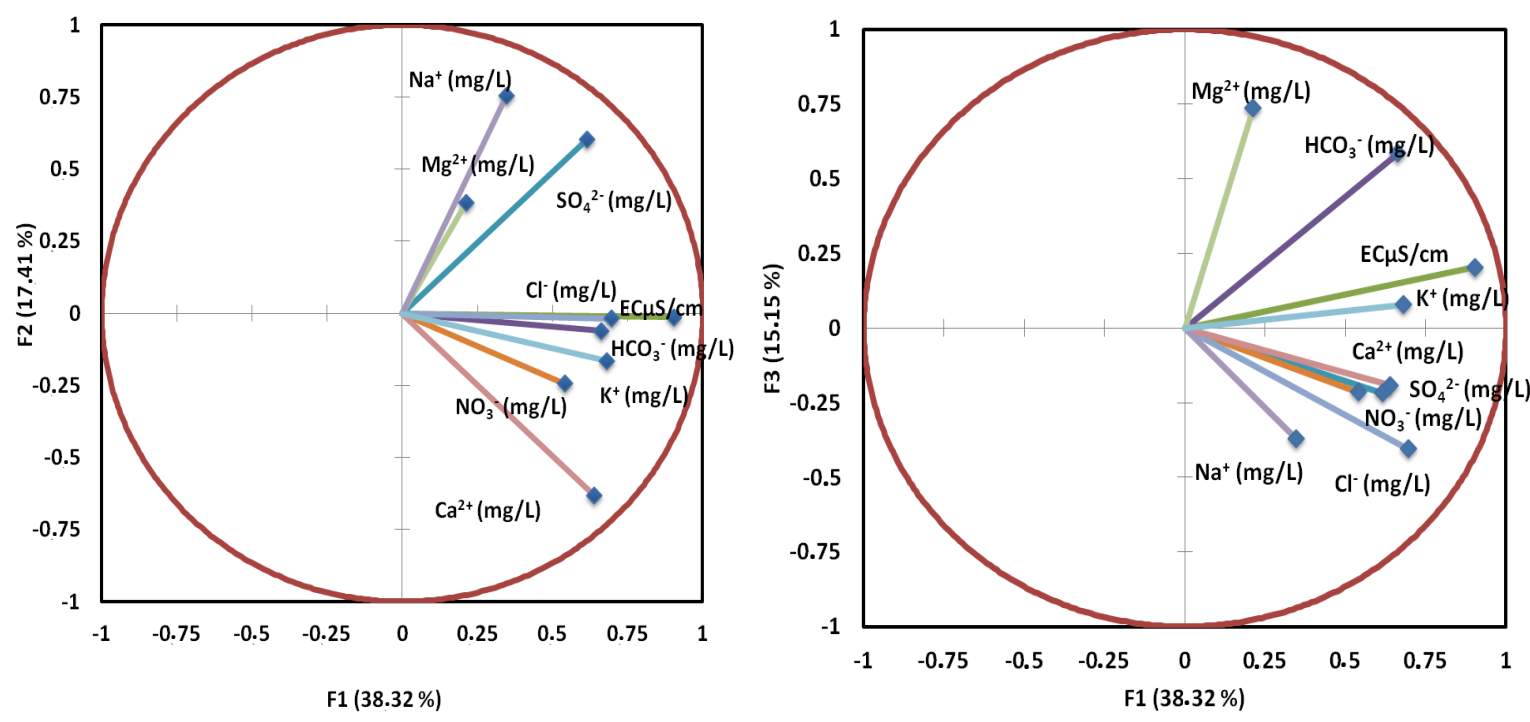

Figure 6. Principal component analysis. Plot of the variables on the F1-F2 plane and on the F1-F3 plane.

contained in the matrix with those present in the groundwater are very variable and depend, among other things, on the nature of the substrate. This ratio is negative when the sodium and potassium contents are high, i.e. when groundwater has been strongly in contact with minerals able to yield these interchangeable cations easily. In the case of the Dogger aquifer, the base exchange index is negative in $93 \%$ of the samples. This indicates that the groundwater exchanged alkaline earths $\mathrm{Ca}^{2+}$ and $\mathrm{Mg}^{2+}$ against the alkalis $\mathrm{Na}^{+}$and $\mathrm{K}^{+}$of clays contained in the underground environment, according to the equation below:

$$
\mathrm{Ca}(\text { water })+2 \mathrm{Na} \text {-clay } \rightarrow \text { Ca-clay }+2 \mathrm{Na}(\text { water })
$$

$\mathrm{Ca}^{2+}$ and $\mathrm{Mg}^{2+}$ can exchange $\mathrm{Na}^{+}$sorbed on the exchangeable sites of the clay minerals, resulting in the increase 
of $\mathrm{Na}^{+}$and the decrease of $\mathrm{Ca}^{2+}$ and $\mathrm{Mg}^{2+}$ in groundwater.

The diagram of $\mathrm{Ca}^{2+} /\left(\mathrm{HCO}_{3}^{-}+\mathrm{SO}_{4}^{2-}\right)$ versus $\mathrm{Na}^{+} / \mathrm{Cl}^{-}$, (Figure 7) shows that the contact of groundwater with the sodic clayey formations in the aquifer supports the losses of calcium due to the process of base exchanges (Quadrants B and C, Figure 7). Figure 7 clearly depicts that calcium is still in deficiency and sodium is in excess.

\subsection{Binary Diagrams}

Binary diagrams between chemical elements were drawn to better understand the processes and specify the likely origin of the major element participating to the groundwater mineralization. The plot of $\mathrm{Na}^{+}$versus $\mathrm{Cl}^{-}$is reported on Figure 8(a). There is no relation between $\mathrm{Na}^{+}$and $\mathrm{Cl}^{-}$and correlation coefficient is not significant

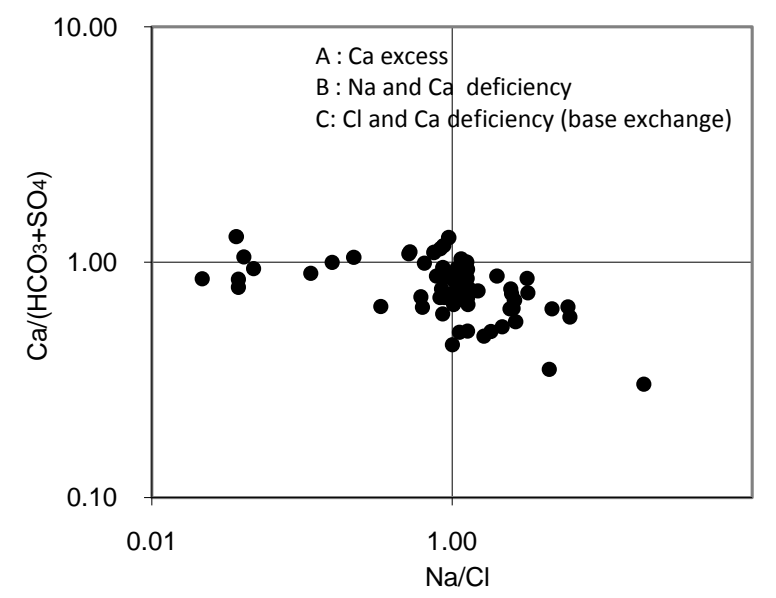

Figure 7. Relationship between $\mathrm{Ca}^{2+} /\left(\mathrm{HCO}_{3}^{-}+\mathrm{SO}_{4}^{2-}\right)$ and $\mathrm{Na}^{+} / \mathrm{Cl}^{-}$ratios.

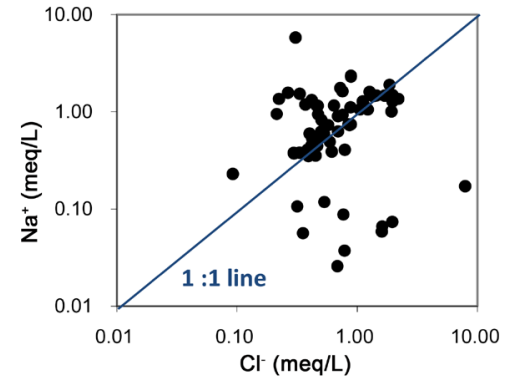

(a)

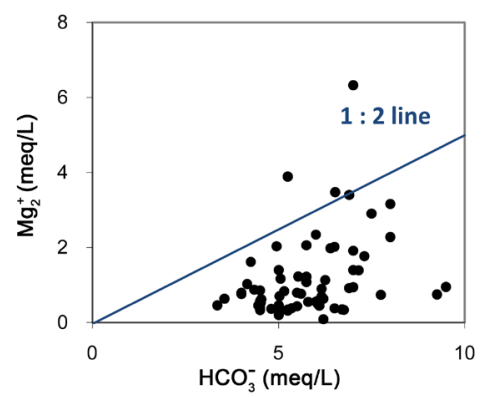

(c)

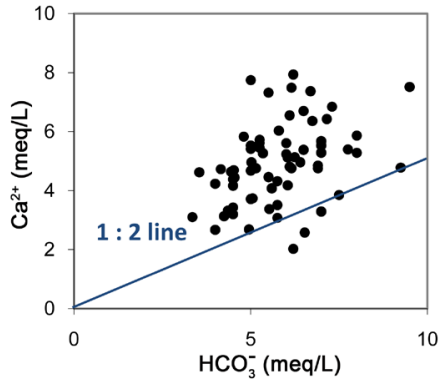

(b)

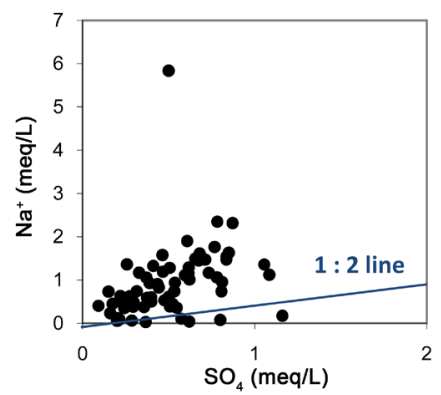

(d)

Figure 8. Relationship between Na-Cl (a); $\mathrm{Ca}-\mathrm{HCO}_{3}$ (b); $\mathrm{Mg}-\mathrm{HCO}_{3}$ (c) and $\mathrm{Na}-\mathrm{SO}_{4}(\mathrm{~d})$. 
$(R=0.29)$. Most of the data in Figure 8(a) deviate from the expected 1:1 line. The plot shows an excess of $\mathrm{Na}^{+}$ in most of the wells. This excess can be explained by a different origin of this element than the dissolution of halite. The high concentrations of $\mathrm{Na}^{+}$which come along with the low concentrations of $\mathrm{Cl}^{-}$can be due to the base exchange phenomena because clays of the substratum can release the ions $\mathrm{Na}^{+}$after having fixed $\mathrm{Ca}^{2+}$. This figure also depicts an enrichment of $\mathrm{Cl}^{-}$in some wells, indicating the effect of another source for this ion than the dissolution of halite. There is a significant relation between $\mathrm{Ca}^{2+}$ and $\mathrm{HCO}_{3}^{-}$with a correlation coefficient of $R=0.45$. The plot of $\mathrm{Ca}^{2+}$ vs. $\mathrm{HCO}_{3}^{-}$(Figure 8(b)) shows an excess of $\mathrm{Ca}^{2+}$. Almost all samples plot above the 2:1 line. This indicates that calcite may not be the main source of $\mathrm{Ca}^{2+}$. Magnesium and bicarbonate are significantly correlated $(R=0.38)$. Figure 8 (c) indicates a deficiency of $\mathrm{Mg}^{2+}$ relative to $\mathrm{HCO}_{3}^{-}$in most of the groundwater samples. This is consistent with the cation exchange between alkaline earths $\left(\mathrm{Ca}^{2+}\right.$ and/or $\left.\mathrm{Mg}^{2+}\right)$ and alkalis $\left(\mathrm{Na}^{+}\right.$and/or $\left.\mathrm{K}^{+}\right)$. The plot of $\mathrm{Na}^{+}$vs. $\mathrm{SO}_{4}^{2-}$ (Figure 8(d)) exhibits a well-defined relationship $(R=$ 0.62 ) but also shows an excess of $\mathrm{Na}^{+}$relative to $\mathrm{SO}_{4}^{2-}$. This supports the assumption that the excess of sodium does not result from the dissolution of sodium sulphate minerals $\left(\mathrm{Na}_{2} \mathrm{SO}_{4}\right)$.

\subsection{Antropogenic Inputs}

Chemical composition of groundwater is generally controlled by inputs through water/rock interaction and also through anthropogenic activities. Variation in TDS in groundwater may be related to land use and also to various contaminants [16] [17]. It is well known that $\mathrm{K}^{+}, \mathrm{NO}_{3}^{-}, \mathrm{SO}_{4}^{2-}, \mathrm{Na}^{+}$and $\mathrm{Cl}^{-}$ions are mostly derived from agricultural fertilizers, animal waste, and municipal sewage. These elements can be used to highlight the influence of human activities on the groundwater chemistry [18].

The Dogger plateau, between the cities of Poitiers and Chauvigny is mainly an agricultural area. Nitrate is commonly and widely applied as a fertiliser. Nitrate can also be derived from other sources like animal excreta and also from nitrification of organic $\mathrm{N}$ and $\mathrm{NH}_{4}^{+}$[19]-[22]. Nitrate values in the Dogger aquifer are relatively high. They vary in a wide range, between 7 and $165 \mathrm{mg} / \mathrm{L}$. In a number of wells, nitrate concentrations exceed $50 \mathrm{mg} / \mathrm{L}$, which represents the maximum admissible nitrate concentration in drinking water. The high contents are related to the agricultural practices. This suggests that the application of nitrogen fertilizers leads to increased nitrate leaching. Besides, the $\mathrm{NO}_{3}^{-}$contents in the groundwater correlate positively with the EC values indicating the significant contribution of this element in the mineralization process.

The main cities and villages are equipped with sewage treatment plants. Farms and isolated houses are equipped with individual wastewater treatment systems. It is well known that poorly functioning individual treatment plants, can be responsible for chloride concentration in groundwater

There is a positive and significant correlation between $\mathrm{NO}_{3}^{-}$and $\mathrm{Ca}^{2+}(R=0.49$, Figure 9(a)), suggesting a common source. Indeed, the positive relationship between $\mathrm{NO}_{3}^{-}$and $\mathrm{Ca}^{2+}$ suggests that both elements are utilized in the Dogger plateau as $\mathrm{Ca}\left(\mathrm{NO}_{3}\right)_{2}$ fertilizers. $\mathrm{Ca}^{2+}$ and $\mathrm{NO}_{3}^{-}$can indeed be associated in some fertilizers. Calcium excess can originate from this source [23].

Positive and significant correlations between $\mathrm{SO}_{4}^{2-}$ and $\mathrm{Cl}^{-}, \mathrm{SO}_{4}^{2-}$ and $\mathrm{Na}^{+}, \mathrm{NO}_{3}^{-}$and $\mathrm{Cl}^{-}, \mathrm{Cl}^{-}$and $\mathrm{Ca}^{2+}$ (Figure 9(b)), $\mathrm{Cl}^{-}$and $\mathrm{K}^{+}$, indicate that these elements derive mainly from anthropogenic activities.

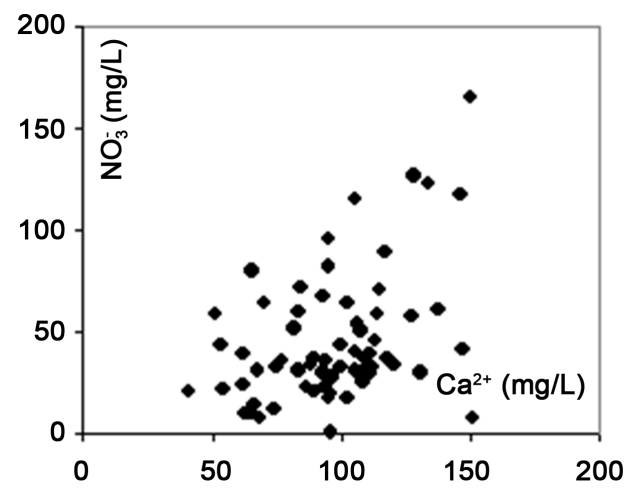

(a)

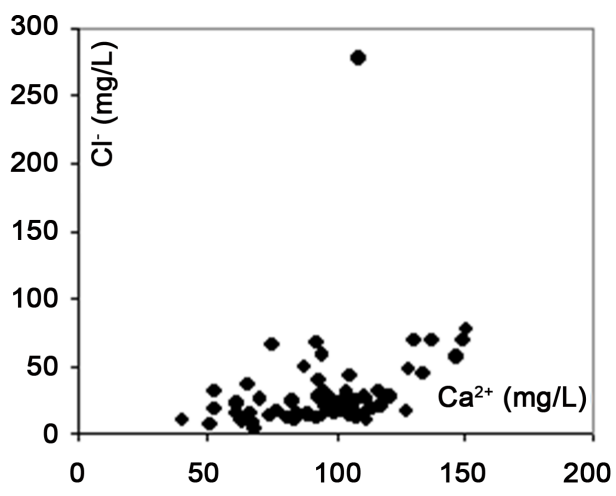

(b)

Figure 9. Relationship between $\mathrm{NO}_{3}^{-}-\mathrm{Ca}^{2+}$ (a) and $\mathrm{Cl}^{-}-\mathrm{Ca}^{2+}(\mathrm{b})$. 


\section{Conclusions}

Chemical properties of groundwater in the Dogger aquifer of Poitiers are controlled both by natural geochemical processes and anthropogenic activities. Dissolution of dolomite and calcite determines $\mathrm{HCO}_{3}^{-}, \mathrm{Ca}^{2+}$ and $\mathrm{Mg}^{2+}$

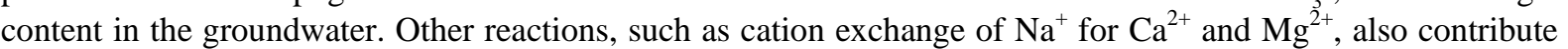
to the content of $\mathrm{Na}^{+}$. The main hydrochemical type water is calcium carbonate. The SI of calcite is generally greater than zero in the area, which suggests that the groundwater is saturated with regards to this mineral.

The use of nitrate fertilizers in the intensively cultivated area of the study area contributes to the increase of the concentration of $\mathrm{NO}_{3}^{-}$. Some elements in excess $\left(\mathrm{Ca}^{2+}, \mathrm{SO}_{4}^{2-}, \mathrm{K}^{+}\right)$may also derive from the application of fertilizers. Poorly treated waste waters can contribute to the input of $\mathrm{Cl}^{-}$in the groundwater.

In general, the groundwater has a chemical composition within the permissible limits suggested for drinking water, except at some places where the nitrate content exceeds the permissible limit $(50 \mathrm{mg} / \mathrm{L})$.

This study adds to our understanding of the mineralization processes of the Dogger groundwater in the Vienne Department and the impact of other influences (agriculture, wastewaters). These findings will be helpful to take measures to prevent spreading of the pollution of this important resource.

\section{References}

[1] WWAP World Water Assessment Programme (2009) United Nations World Water Development, Report 3: Water in a Changing World. UNESCO, Paris.

[2] Lloyd, W.J. and Heathcote, A.J. (1985) Natural Inorganic Chemistry in Relation to Groundwater. Claredon Press, Oxford, $250 \mathrm{p}$.

[3] Parkhurst, D.L. and Appelo, C.A. (1999) User’s Guide to PHREEQC (Version 2)—A Computer Program for Speciation, Batch-Reaction, One-Dimensional Transport, and Inverse Geochemical Calculations. United States Geological Survey, Water Resources Investigations Report 99-4259, Washington DC, 326 p.

[4] Saporta, D (1990). Probabilités, Analyse de données et Statistique. Ed.Technip, Paris, 493 p.

[5] Dawdy, D.R. and Feth, J.H. (1967) Application of Factor Analysis in Study of Chemistry of Groundwater Quality, Mojave River Valley, California. Water Resources Research, 3, 505-510. http://dx.doi.org/10.1029/WR003i002p00505

[6] Razack, M. and Dazy, J. (1990) Hydrogeochemical Characterization of Groundwater Mixing in Sedimentary and Metamorphic Reservoirs with Combined use Of Piper's Principle and Factor Analysis. Journal of Hydrology, 114, 371393. http://dx.doi.org/10.1016/0022-1694(90)90066-7

[7] Jayakumar, R. and Siraz, L. (1997) Factor Analysis in Hydrogeochemistry of Coastal Aquifers-A Preliminary Study. Environmental Geology, 31, 174-177. http://dx.doi.org/10.1007/s002540050177

[8] Suk, H. and Lee, K. (1999) Characterization of a Groundwater Hydrochemical System through Multivariate Analysis: Clustering into Groundwater Zones. Groundwater, 37, 358-366. http://dx.doi.org/10.1111/j.1745-6584.1999.tb01112.x

[9] Saldarriaga-Noreña, H., de la Garza-Rodríguez, I., Waliszewski, S., Colunga-Urbina, E., Amador-Muñoz, O., MorenoDávila, M. and Morales-Cueto, R. (2014) Chemical Evaluation of Groundwater from Supply Wells in the State of Coahuila, México. Journal of Water Resource and Protection, 6, 49-54. http://dx.doi.org/10.4236/jwarp.2014.61008

[10] Hosseinimarandi, H., Mahdavi, M., Ahmadi, H., Motamedvaziri, B. and Adelpur, A. (2014) Assessment of Groundwater Quality Monitoring Network Using Cluster Analysis, Shib-Kuh Plain, Shur Watershed, Iran. Journal of Water Resource and Protection, 6, 618-624. http://dx.doi.org/10.4236/jwarp.2014.66060

[11] Ruiz, F., Gomis, V. and Blasco, P. (1990) Application of Factor Analysis to the Hydrogeochemical Study of a Coastal Aquifer. Journal of Hydrology, 119, 169-177. http://dx.doi.org/10.1016/0022-1694(90)90041-U

[12] Kaiser, H.F. (1958) The Varimax Criteria for Analytical Rotation in Factor Analysis. Psychometrika, 23, 187-200. http://dx.doi.org/10.1007/BF02289233

[13] Harman, H.H. (1960) Modern Factor Analysis. University of Chicago Press, Chicago

[14] Rao, Y.S., Reddy, T.V.K. and Nayudu, P.T. (1997) Groundwater Quality in the Niva River Basin, Chittoor District, Andhra Pradesh, India. Environmental Geology, 32, 56-63. http://dx.doi.org/10.1007/s002540050193

[15] Schoeller, H. (1977) Geochemistry of Groundwater. In: Brown, R.H., Konoplyantsev, A.A., Ineson, J. and Kovalevsky, V.S., Eds., Groundwater Studies: An International Guide for Research and Practice, UNESCO, Paris, 1-18.

[16] Ellaway, M., Finlayson, B. and Webb, J. (1999) The Impact of Land Clearance on Karst Ground Water: A Case Study from Buchan, Victoria, Australia. In: Drew, D. and Hotzl, H., Eds., Karst Hydrogeology and Human Activities, A.A. Balkema, Rotterdam, 66-68.

[17] Gillardet, J., Dupre, B., Louvat, P. and Allegre, C.J. (1999) Global Silicate Weathering and $\mathrm{CO}_{2}$ Consumption Rates 
Deduced from the Chemistry of Large Rivers. Chemical Geology, 159, 3-30. http://dx.doi.org/10.1016/S0009-2541(99)00031-5

[18] Han, G. and Liu, C.-Q. (2004) Water Geochemistry Controlled by Carbonate Dissolution: A Study of the River Waters Draining Karst-Dominated Terrain, Guizhou Province, China. Chemical Geology, 204, 1-21. http://dx.doi.org/10.1016/j.chemgeo.2003.09.009

[19] Savoie, D.L. and Prospero, J.M. (1989) Comparison of Oceanic and Continental Source of Non-Sea-Salt Sulfate over the Pacific Ocean. Nature, 339, 685-687. http://dx.doi.org/10.1038/339685a0

[20] Agrawal, G.D., Lunkad, S.K. and Malkhed, T. (1999) Diffuse Agricultural Nitrate Pollution of Groundwaters in India. Water Science and Technology, 39, 67-75. http://dx.doi.org/10.1016/S0273-1223(99)00033-5

[21] Jeong, C.H. (2001) Effect of Land Use and Urbanization on Hydrochemistry and Contamination of Groundwater from Taejon Area, Korea. Journal of Hydrology, 253, 194-210. http://dx.doi.org/10.1016/S0022-1694(01)00481-4

[22] Xiao, H.Y. and Liu, C-Q. (2002) Sources of Nitrogen and Sulfur in Wet Deposition at Guiyang, Southwest China. Atmospheric Environment, 36, 5121-5130. http://dx.doi.org/10.1016/S1352-2310(02)00649-0

[23] Stigter, T.Y., Carvalho, A.M., Ribeiro, L. and Reis, E. (2006) Impact of the Shift from Groundwater to Surface Water Irrigation on Aquifer Dynamics and Hydrochemistry in a Semi-Arid Region in the South of Portugal. Agricultural Water Management, 85, 121-132. http://dx.doi.org/10.1016/j.agwat.2006.04.004 
Scientific Research Publishing (SCIRP) is one of the largest Open Access journal publishers. It is currently publishing more than 200 open access, online, peer-reviewed journals covering a wide range of academic disciplines. SCIRP serves the worldwide academic communities and contributes to the progress and application of science with its publication.

Other selected journals from SCIRP are listed as below. Submit your manuscript to us via either submit@scirp.org or Online Submission Portal.
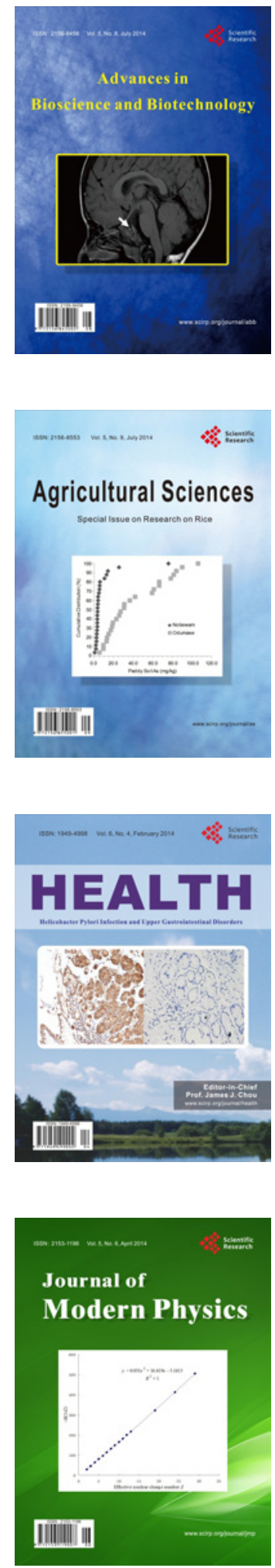
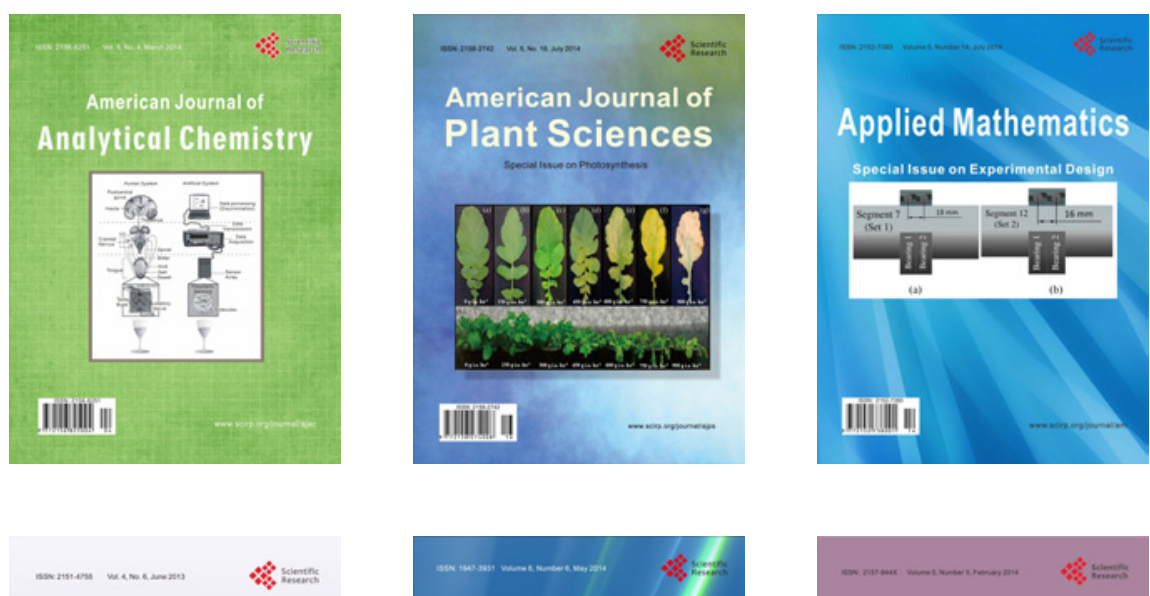

Creative Education
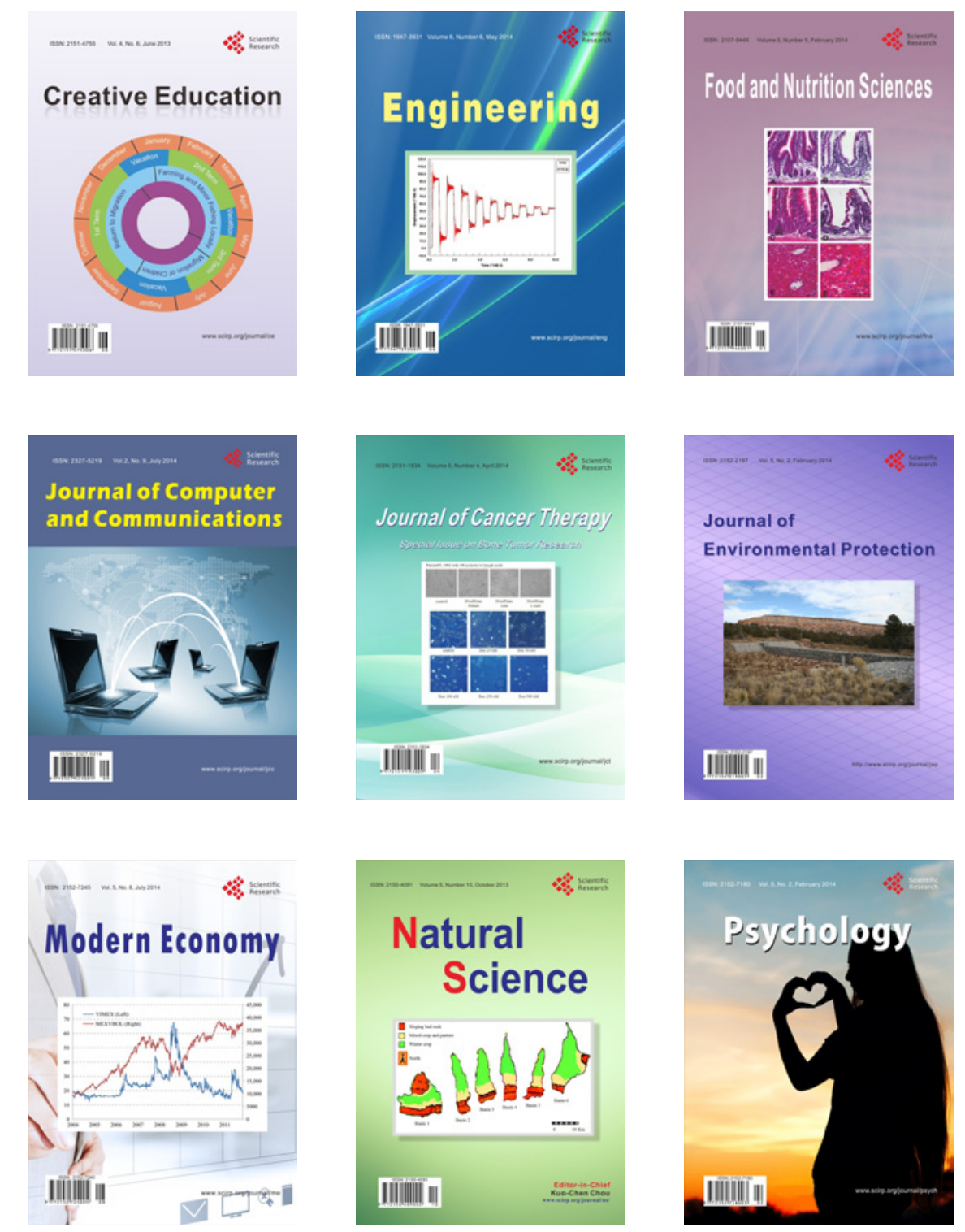